required not only to prove that the proposed subtenant meets reasonable commercial standards of credit and reputation but also to disprove any particular allegations that the landlord's interests would be damaged by the proposed subtenancy. This solution allows the landlord to protect his legitimate business interests and to meet the legal requirements of care in tenant selection, for he can still, in the exercise of reasonable discretion, reject a truly undesirable subtenant. At the same time it relieves the tenant from unnecessary hardship and permits more efficient utilization of the community's economic resources.

$\$ 1057$, at 280 (1951). Similarly, a clause which exempts a party from his obligation to avoid damages should not be enforced since justice does not require compensation for harm needlessly suffered.

\title{
COLLECTION CAPERS: LIABILITY FOR DEBT COLLECTION PRACTICES
}

The legality of widespread debt collection practices has been a fertile and ever-increasing source of controversy. The creditor, or more commonly a collection agency, may continually hound the debtor with threats ranging from the institution of legal proceedings to the economic and social pressure afforded by exposure of the debtor's financial circumstances to others. Moreover, as illustrated by several recent cases, these threats are in many instances carried out. ${ }^{1}$ This comment will discuss the existing legal restrictions on such collection activity with the aim of delineating the boundaries of permissible conduct.

\section{Unauthorized Practice of Law}

The creditor seeking payment will often enlist the services of a commercial collection agency. Conflict between certain practices followed by these agencies and the efforts of the bar to eliminate lay competition forms a focal point for present legal dispute. ${ }^{2}$ When such conflict exists, the sanction may be formidable. The layman who is held to be engaged in the unauthorized prac-

\footnotetext{
${ }^{1}$ For descriptions of collection activity consult, e.g., Housh v. Peth, 165 Ohio St. 35, 133 N.E.2d 340 (1956), noted in 7 West. Res. L. Rev. 461 (1956), and 2 Wayne L. Rev. 240 (1956); Duty v. General Finance Co., 154 Tex. 16, 273 S.W.2d 64 (1954). Consult also Butterfield, Collection Agencies and the Courts, 5 Law \& Contemp. Prob. 47 (1938) ; Birkhead, Collection Tactics of Illegal Lenders, 8 Law \& Contemp. Prob. 78 (1941); Otterbourg, Collection Agency Activities: The Problem from the Standpoint of the Bar, 5 Law \& Contemp. Prob. 35 (1938) ; Nugent, Devices for Liquidating Small Claims in Detroit, 2 Law \& Contemp. Prob. 259 (1935) ; Harris, Improper Methods of Collecting Debts, 58 Com. L. J. 5 (1953).

${ }^{2}$ Consult Johnstone, The Unauthorized Practice Controversy, A Struggle Among Power Groups, 4 Kan. L. Rev. 1 (1955), for an exhaustive treatment. Closely analogous to activities of the American Bar Association in this regard are the activities of the American Medical Association, discussed in The American Medical Association: Power, Purpose and Policies in Organized Medicine, 63 Yale L. J. 938 (1954).
} 
tice of law will be enjoined from continuing such activities under penalty of fine or even imprisonment, ${ }^{3}$ or possibly found in contempt of court. ${ }^{4}$

As a general rule, the collection agency, insofar as it is a lay organization, may not represent the creditor in court..$^{5}$ Furthermore, this prohibition may not be circumvented by a nominal assignment of the claim in such a manner as to entitle the agency to proceed as an apparent real party in interest. ${ }^{\circ}$ Some jurisdictions, however, permit lay employees of agencies to act as "attorneys" before justice of the peace "courts" either because of the technical view that such a tribunal is not a court at all ${ }^{7}$ or because of authorization by special statute. ${ }^{8}$

Collection agencies may also engage in the unauthorized practice of law by advising creditors with respect to legal matters ${ }^{9}$ or by drafting legal instruments for them. ${ }^{10}$ The test generally applied in this area is whether or not the activity in question requires for its proper performance techniques, skills

\footnotetext{
${ }^{3}$ E.g., Keyes Co. v. Dade County Bar Ass'n, 46 So.2d 605 (Fla., 1950).

'E.g., People ex rel. Chicago Bar Ass'n v. Chicago Motor Club, 362 Ill. 50, 199 N.E. 1 (1935).

${ }^{5}$ See, e.g., Depew v. Wichita Ass'n of Credit Men, Inc., 142 Kan. 403, 49 P.2d 1041 (1935). Laymen apparently never seek to represent other lay persons in court. But disbarred attorneys, or attorneys not admitted in the state in which they appear, prove the rule when they seek to appear in court in a representative capacity. Petition of Kearney, 63 So.2d 630 (Fla., 1953); Horne v. Bridwell, 193 Va. 381, 68 S.E.2d 535 (1952); People ex rel. Chicago Bar Ass'n v. Novotny, 386 Ill. 536, 54 N.E.2d 536 (1944). Principle (1) of the Joint Statement of Principles issued by the American Bar Ass'n Committee on The Unauthorized Practice of Law and Representatives of Collection Agencies, May 4, 1937, printed in II Martindale-Hubbell Law Directory 105A (88th ed., 1956), provides: "It is improper for a collection agency (1) to furnish legal advice or to perform legal services or to represent that it is competent to do so; or to institute judicial proceedings on behalf of
} other persons."

- Bay County Bar Ass'n v. Finance System, Inc., 345 Mich. 434, 76 N.W.2d 23 (1956). Accord: Nelson v. Smith, 107 Utah 382, 154 P.2d 634 (1944); Bump v. Barnett, 235 Iowa 308, 16 N.W.2d 579 (1944). Cf. People ex rel. Chicago Bar Ass'n v. Barasch, 406 Ill. 253, 94 N.E.2d 148 (1950). But cf. Washington State Bar Ass'n v. Merchants' R. \& A. Co., 183 Wash. 611, 49 P.2d 26 (1935). Consult 17 Unauthorized Practice News, No. 4, at 57 (1951).

"Consult United Securities Corp. v. Pantex Pressing Mach., Inc., 98 Colo. 79, 53 P.2d 653 (1935) ; Rehm v. Cumberland Coal Co., 169 Md. 365, 181 Atl. 724 (1935). For the majority view disqualifying lay persons from appearing in a representative capacity even before justice of the peace courts, consult, e.g., State ex rel. Hunter v. Kirk, 133 Neb. 625, 276 N.W. 380 (1937) ; State ex rel. Dist. Atty. v. Lytton, 172 Tenn. 91, 110 S.W.2d 313 (1937). A similar exclusion applies to the probate court. In re Root, 173 Kan. 512, 249 P.2d 628 (1952) ; Grand Rapids Bar Ass'n v. Denkema, 290 Mich. 56, 287 N.W. 377 (1939).

${ }^{8}$ E.g., Wis. Stat. (1955) $\$ 301.20$, discussed in Can A Person Other Than a Licensed Attorney Practice in Justice Court? [1948] Wis. L. Rev. 537.

- Consult, e.g., State ex rel. Fatzer v. Schmitt, 174 Kan. 581, 258 P.2d 228 (1953) (trust advisory service) ; Fitchette v. Taylor, 191 Minn. 582, 254 N.W. 910 (1934) (claims adjuster advised and negotiated settlements).

${ }^{10}$ Oklahoma Bar Ass'n v. Gentry, reported in 20 Unauthorized Practice News, No. 1, at 18 (1954) (Dist. Ct., Okla., 1953) (garnishment affidavits and bills of particulars). A case reported in 17 Unauthorized Practice News, No. 3, at 36 (1951), involved a fine of $\$ 800$ 
and training typically associated with the legal profession.11 As sometimes stated, it is the character of the act and not whether it was performed before a court which is controlling. ${ }^{12}$ Thus, it has been beld that a collection agency may complete blank notes, drafts, mortgage forms and similar forms obtainable at any bookstore if filling them out requires no special legal knowledge. ${ }^{13}$ On the other hand there are many cases which hold that selection of the proper form and its completion by a lay person is unauthorized because it requires legal skill and knowledge. ${ }^{14}$

There is, however, an important qualification to the general "legal skills" test. Many courts state that a layman may engage in what are otherwise legal activities if these activities are "incidental to his regular calling." 15 So stated,

upon a Wisconsin collector under the Wisconsin Collection Agency Licensing Law $(\$ 256.30$ [2]) for obtaining and causing to be issued an execution on a judgment already entered. Consult also Yount v. Zarbell, 17 Wash.2d 278, 135 P.2d 309 (1943) (pleadings); Depew v. Wichita Ass'n of Credit Men, Inc., 142 Kan. 403, 49 P.2d 1041 (1935) (preparing bills of particulars and intervening petitions). Consult Statement of Principles, loc. cit. supra note 5 . The rule is one of wide application. Thus, it has been held illegal for realtors to prepare deeds, contracts of sale, mortgages and notes. Washington State Bar Ass'n v. Washington Ass'n of Realtors, 41 Wash.2d 697, 251 P.2d 619 (1952) (deeds); Keyes Co. v. Dade County Bar Ass'n, 46 So.2d 605 (Fla., 1950) (deeds, leases and mortgages, but a realtor may prepare contracts of sale); People ex rel. Illinois State Bar Ass'n v. Schafer, 404 IIl. 45, 87 N.E.2d 773 (1949) (contracts, deeds, mortgages and notes). It has likewise been held illegal for banks and trust companies to prepare wills, trusts, etc. Hobson v. Kentucky Trust Co., 303 Ky. 493, 197 S.W.2d 454 (1946) (deeds and wills, at least if compensation is demanded). And it is unlawful for independent claims adjusters to prepare contracts settling claims. State ex rel. Junior Ass'n of Milwaukee Bar v. Rice, 236 Wis. 38, 294 N.W. 550 (1940). It is also unlawful for title or abstract companies to prepare title opinions, deeds or similar instruments. Steer v. Land Title Guarantee \& Trust Co., 113 N.E.2d 763 (Ohio C.P., 1953). But cf. La Brum v. Commonwealth Title Co., $368 \mathrm{~Pa}$. 239, 56 A.2d 246 (1948) (title companies may draft instruments collateral to the insuring of titles). Patent agents may not prepare patent applications, assignments, leases, etc. Chicago Bar Ass'n v. Kellogg, 338 Il.App. 618, 88 N.E.2d 519 (1949). Contra: Marshall v. New Inventors Club, Inc., 117 N.E.2d 737 (Ohio C.P., 1953).

${ }^{11}$ Agran v. Shapiro, 273 P.2d 619 (Cal. Super.Ct., 1954) ; Gardner v. Conway, 234 Minn. 468, 48 N.W.2d 788 (1951); Stack v. P. G. Garage, Inc., 7 N.J. 118, 80 A.2d 545 (1951).

${ }^{12}$ Shortz v. Farrell, 327 Pa. 81, 193 Atl. 20 (1937); People ex rel. Chicago Bar Ass'n v. Goodman, 366 Ill. 346, 8 N.E.2d 941 (1937); In re Ripley, 109 Vt. 83, 191 Atl. 918 (1937). One court has suggested that community custom is significant. Lowell Bar Ass'n v. Loeb, 315 Mass. 176, 52 N.E.2d 27 (1943).

${ }^{13}$ Depew v. Wichita Ass'n of Credit Men, 142 Kan. 403, 49 P.2d 1041 (1935).

${ }^{14}$ Washington State Bar Ass'n v. Washington Ass'n of Realtors, 41 Wash.2d 697, 251 P.2d 619 (1952) (realtor); Chicago Bar Ass'n v. Kellogg, 338 Ill.App. 618, 88 N.E.2d 519 (1949) (patent agent); In re Gore, 58 Ohio App. 79, 15 N.E.2d 968 (1937) (realtor). To the effect that there is no basis for distinguishing between simple and complex instruments see Hexter Title \& Abstract Co. v. Grievance Committee, 142 Tex. 506, 179 S.W.2d 946 (1944); People v. Lawyers Title Corp., 282 N.X. 513, 27 N.E.2d 30 (1940) ; L. Meisel \& Co. v. National Jewelers Board of Trade, 90 Misc. 19, 152 N.Y.Supp. 913 (S.Ct., 1915).

${ }^{15}$ Petitions of Ingham County Bar Ass'n, 342 Mich. 214, 69 N.W.2d 713 (1955); Hulse v. Criger, 363 Mo. 26, 247 S.W.2d 855 (1952); Keyes Co. v. Dade County Bar Ass'n, 46 So.2d 
this rule would appear to conflict with the "legal skills" test, for it may be assumed that in most instances the layman's activities are related to his usual business. Alternatively, the "incidental" test would appear to mean that if the layman is deemed to possess, by reason of the nature of his business, what are legal skills and techniques, then he may properly use these abilities and will not be found to be engaged in the unauthorized practice of law. In fact, such a view seems in harmony with the justification generally advanced to support the "monopoly" given lawyers as to the practice of law: protection of the public from the ignorant and unscrupulous "through the requirement of high standards of preparation and ability."16 Thus, it has been held that banks, ${ }^{17}$ realtors ${ }^{18}$ and tax advisers ${ }^{19}$ may perform many tasks involving relatively complex legal problems. As applied to collection agencies, the "incidental" test may therefore afford some leeway for the drafting of instruments and giving of advice concerning matters which are closely associated with debt collection.

The collection agency may attempt to avoid the effect of the rules prohibiting it from going to court or otherwise engaging in lawyer-like activity through an arrangement whereby attorneys are employed to handle the legal matters incident to the claims solicited by the agency. Such an arrangement, widespread though it may be, is fraught with legal dangers. Thus, a partnership agreement under which claims are solicited by lay members of a firm and suits are brought thereon by an attorney member has been held void and unenforceable by reason of the public policy against lay practice of law. ${ }^{20}$ Similarly, the employment of attorneys by an agency on a commission basis for the bringing of suit has been held to constitute the unauthorized practice of law. ${ }^{21}$

605 (Fla., 1950) ; State ex rel. Johnson v. Childe, 139 Neb. 91, 295 N.W. 381 (1941); Gustafson v. V. C. Taylor \& Sons, Inc., 138 Ohio St. 392, 35 N.E.2d 435 (1941); Cain v. Merchants Nat'l Bank \& Trust Co., 66 N.D. 746, 268 N.W. 719 (1936) ; Childs v. Smeltzer, 315 Pa. 9, 171 Atl. 883 (1934).

${ }^{16}$ Dade County Bar Ass'n v. Keyes Company, C.C. of Dade County, Fla., No. 110, 350-A (1949) (not officially reported), quoted at length in 15 Unauthorized Practice News, No. 1, at 8 (1949), reversed in part, 46 So.2d 605 (Fla., 1950).

${ }^{17}$ E.g., Cain v. Merchants Nat'l Bank \& Trust Co., 66 N.D. 746, 268 N.W. 719 (1936).

${ }^{18}$ E.g., Keyes Co. v. Dade County Bar Ass'n, 46 So.2d 605 (Fla., 1950) (realtor may prepare contracts of sale, but not deeds, leases and mortgages); Cowern v. Nelson, 207 Minn. 642, 290 N.W. 795 (1940) (closing instruments, if drafted free of charge).

${ }^{19}$ E.g., Lowell Bar Ass'n v. Loeb, 315 Mass. 176, 52 N.E.2d 27 (1943).

${ }^{20}$ Waychoff v. Waychoff, 309 Pa. 300, 163 Atl. 670 (1932) ; Midland Credit Adjustment Co. v. Donnelley, 219 Mll.App. 271 (1920) (contract held void).

${ }^{24}$ Depew v. Wichita Ass'n of Credit Men, 142 Kan. 403, 49 P.2d 1041 (1935). It has even been held that a non-profit lay association may not perform legal services for members. People ex rel. Chicago Bar Ass'n v. Chicago Motor Club, 362 Ill. 50, 199 N.E. 1 (1935). But cf. Vitaphone Corp. v. Hutchinson Amusement Co., 28 F.Supp. 526 (D. Mass., 1939). And consult Weihofen, "Practice of Law" by Non-Pecuniary Corporations: A Social Utility, 
Implicit in such decisions is the proposition that the supplying of professional services through others amounts to the practice of the profession. ${ }^{22}$ Thus, they suggest that whenever the agency acts as intermediary between the creditor and the attorney by controlling the attorney's selection, compensation or activities, or whenever the agency exercises its own discretion in settling or compromising claims of others, or in determining whether legal proceedings should be instituted, unauthorized practice is likely to be found. ${ }^{23}$ In other words, one who may not practice law directly may not do so indirectly through the employment of a lawyer to practice for him. ${ }^{24}$

In conclusion, it will be noted that the judiciary has assumed a controlling position in determining what is the permissible practice of law. ${ }^{25}$ Statutes and

2 U. of Chi. L. Rev. 119 (1934). It has also been held that a corporate trust company may not permit its employed attorneys to draft trusts when it is to act as fiduciary under the instruments being drafted, since this is essentially the performing of legal services not for itself, but for others. Arkansas Bar Ass'n v. Union Nat'l Bank of Little Rock, 224 Ark. 48, 273 S.W.2d 408 (1954). Consult also Steer v. Land Title Guarantee \& Trust Co., 113 N.E.2d 763 (Ohio C.P., 1953) (corporation selling title opinions of its salaried lawyer employees).

${ }^{22}$ In re Cooperative Law Co., 198 N.Y. 479, 92 N.E. 15 (1910) (lawyers); People v. Dermatological Institute, 192 N.Y. 454, 85 N.E. 697 (1908) (doctors). Cf. Rosenthal v. Shepard Broadcasting Service, 299 Mass. 286, 12 N.E.2d 819 (1938) (radio program giving legal advice).

${ }^{23}$ See State ex rel. McKittrick v. C. S. Dudley \& Co., 340 Mo. 852, 102 S.W.2d 895 (1937); Matter of Shoe Manufacturer's Protective Ass'n, 295 Mass. 369, 3 N.E.2d 746 (1936). Consult Johnstone, op. cit. supra note 2, at 9; Otterbourg, Collection Agency Activities: The Problem from the Standpoint of the Bar, 5 Law \& Contemp. Prob. 35, 37-38 (1938) ; Brand, Unauthorized Practice Decisions 767 (1937). Statement of Principles, loc. cit. supra note 5, at 105A provides inter alia: "It is improper for a collection agency: . . . (6) To assume authority on behalf of creditors to employ or terminate the services of an attorney or to arrange the terms or compensation for such services. (7) To intervene between creditor and attorney in any manner which would control or exploit the services of the attorney or which would direct those services in the interest of the agency. (8) To demand or obtain in any manner a share of the proper compensation for services performed by an attorney in collecting a claim, irrespective of whether or not the agency may have previously attempted collection thereof." Consult also cases cited notes 20-22 supra.

2s "As [a corporation] cannot practice law directly, it cannot indirectly by employing competent lawyers to practice for it, as that would be an evasion which the law will not tolerate." In re Cooperative Law Co., 198 N.Y. 479, 483, 92 N.E. 15, 16 (1910). Similarly, a lay person may not represent others by hiring a lawyer to do the legal work. Chicago Bar Ass'n v. Clauson, 1 Ill.App.2d 140, 117 N.E.2d 321 (1953) (service to represent in condemnation proceedings); Stack v. P. G. Garage, 7 N.J. 118, 80 A.2d 545 (1951) (tax reduction service); Lowell Bar Ass'n v. Loeb, 315 Mass. 176, 52 N.E. $2 d 27$ (1943) (same); People ex rel. Chicago Bar Ass'n v. Chicago Motor Club, 362 Ill. 50, 199 N.E. 1 (1935) (auto club).

The lawyer who is the subject of the improper hiring may himself incur a special type of liability by taking part in collection practices which may be deemed "unethical." Consult In re Disbarment of Dows, 168 Minn. 6, 209 N.W. 627 (1926); In re Swihart and Branson, 42 S.D. 628,177 N.Y. 364 (1920), both of which involve the simulation of legal process.

${ }^{25}$ Consult, e.g., People ex rel. Illinois State Bar Ass'n v. People's Stock Yards State Bank, 344 III. 462, 176 N.E. 901 (1931). 
regulations have had little influence. ${ }^{26}$ Indeed, it has been held that they must be consistent with judicial decisions to be valid. ${ }^{2 \pi}$ Those non-legal groups which achieve proficiency in specialized areas of the law will doubtless continue to assert the right to give service in those areas, but neither bar nor bench seems prepared to yield much ground. Thus, collection agencies may often run the risks inherent in proceedings brought by a jealous bar and decided by unfriendly courts. ${ }^{28}$

\section{Federal and State Penal Statutes}

Significant federal regulation has taken two forms. In 1888, Congress acted to prohibit the use of the mails for the sending of matter which on its face carries an imputation of bad credit, ${ }^{29}$ a practice which had been held permissible under the prior statute. ${ }^{30}$ Thus, an envelope on which the words "Excelsior Collection Agency" are printed "in very large full-faced capital letters" may be excluded from the mails. ${ }^{31}$ Also, some collection agency procedures are likely to be designated "unfair methods of competition" by the Federal Trade Commission. ${ }^{32}$

${ }^{2}$ Some statutes merely prohibit practice of law by lay persons. E.g., Neb. Rev. Stat. (1954) \$ 7-101. Others attempt a rough definition. E.g., Wis. Stat. (1955) $\$ 256.30$. Still others enumerate specific practices of specific businesses as lawful or unauthorized. E.g., Minn. Stat. (1953) \$481.02.

${ }^{27}$ People ex rel. Chicago Bar Ass'n v. Goodman, 366 Ill. 346, 8 N.E.2d 941 (1937).

${ }^{28}$ Understandably enough, laymen seem to avoid instituting court tests as to the legality of their practices. The only case found in which a lay group sought a ruling with respect to the legality of its activities is Liberty Mutual Ins. Co. v. Jones, 344 Mo. 932, 130 S.W.2d 945 (1939).

${ }^{2} 25$ Stat. 188 (1888), 18 U.S.C.A. $\$ 1718$ (1950): "All matter . . . upon the envelope or outside cover or wrapper of which, or any postal card upon which is written or printed or otherwise impressed or apparent any delineation, epithet, term, or language of libelous . . character, or calculated by the terms or manner or style of display and obviously intended to reflect injuriously upon the character or conduct of another, is nonmailable matter. . . . Whoever knowingly deposits for mailing or delivery, anything declared by this section to be nonmailable ... shall be fined . . . or imprisoned. . . ."

${ }^{30}$ Ex parte Doran, 32 Fed. 76 (D. Minn., 1887). The previous statute, 13 Stat. 507 (1865), had been directed solely at obscene matter.

${ }^{51}$ United States v. Brown, 43 Fed. 135, 136 (C.C. Vt., 1890). The statute was also held to be violated by the mailing of postcards which contained dunning communications and threats of suit in United States v. Bayle, 40 Fed. 664 (E.D. Mo., 1889), and United States v. Prendergast, 237 Fed. 410 (D. Ore., 1916).

${ }^{32}$ The FTC has recently acted to forestall the activities of several collectors in the Washington, D.C., area, who used "imposing looking names, seals, eagles, etc., obviously to delude the ignorant debtor into believing that his shortcomings in meeting his obligations had finally become the subject of official government inquiry and concern." 22 Unauthorized Practice News, No. 2, at 57 (1956). See also 22 Unauthorized Practice News, No. 2, at 61 (1956), reporting that the "Retail Board of Trade, Chicago" had been ordered by the FTC examiner to stop using that name in its collection activities, the examiner holding that the name implies that the concern is an organization of retailers. The agency thus "misrepresents that 
The imposition of criminal liability under state statutes will depend largely on the particular wording of the statute and local enforcement policies.33 For example, extreme pressuring of the debtor by threats of violence, criminal proceedings or exposure has been said to fall within common definitions of assault, ${ }^{34}$ extortion, ${ }^{35}$ and blackmail. ${ }^{36}$ In similar circumstances prosecutions for criminal libel ${ }^{37}$ and other misdemeanors ${ }^{38}$ have been sustained. The existence of a just debt with few exceptions ${ }^{39}$ is not recognized as a defense.

Nevertheless, the paucity of reported cases suggests uneven enforcement and perhaps total acceptance by local prosecutors of prevailing collection practices. This situation is of course aggravated by the difficulty in drawing a line between permissible and prohibited collection activity.

it is to the advantage of the debtor to answer inquiries from the company," it being a "credit-rating agency."

It is perhaps noteworthy that collection of private debts on government property without prior permission is forbidden by a federal regulation. 44 Code Fed. Regs. $\$ 100.8$ (Supp., 1955), issued pursuant to 62 Stat. 281 (1948), 40 U.S.C.A. $\$ 318$ a (1950). A collector was recently fined $\$ 25.00$ under this regulation for attempting to collect money from a borrower at his place of work in the Health, Education and Welfare Department Building. U.S. v. Sipple, 10 Consumer Finance Law Bull. 7 (1956) (Mun.Ct., D.C., 1955).

${ }^{33}$ Compare, at two extremes, People v. Loveless, 84 N.Y.Supp. 1114 (N.Y. Spec.Sess. Ct., 1903) (letter threatening to expose non-payment of a just debt held a misdemeanor under statute making illegal the sending of letters whose effect is to cause annoyance) with Barton v. State, 88 Tex.Crim.Rep. 368, 227 S.W. 317 (1921) (conviction for assault with intent to commit robbery reversed, for the offense, blow with a pistol and intent to kill, was not made out for lack of the requisite intent, since defendant "acted alone upon the intent to collect the debt, which he in good faith believed to be owing").

* State v. Hollyway, 41 Iowa 200 (1875) (threat to shoot with drawn revolver). But cf. Barton v. State, 88 Tex.Crim.Rep. 368, 227 SW. 317 (1921).

${ }^{85}$ Cf. Weeber v. United States, 62 Fed. 740 (C.C. Colo., 1894) (federal statute). Consult cases cited notes 38 and 39 infra. Cf. Slater v. Taylor, 31 App.D.C. 100 (1908), where it was held in a suit for false imprisonment that defendant had just cause to procure plaintiff's arrest for extortion when plaintiff posted numerous cards conspicuously on plaintiff's door with the purpose of coercing payment of a sum claimed to be due.

${ }^{30}$ See State v. Richards, 97 Wash. 587, 589, 167 Pac. 47, 48 (1917). The court stated that "[t] he law does not countenance forceful and unlawful collection even of just debts. . . . [O]ne can commit ... [blackmail] though he is of the opinion that the money thus sought is actually due him."

${ }^{37}$ Cf. State v. Armstrong, 106 Mo. 395, 16 S.W. 604 (1891) (creditor liable for agency's exposure of debtor's financial circumstances to employer).

${ }^{38}$ People v. Loveless, 84 N.Y.Supp. 1114 (N.Y. Spec.Sess.Ct., 1903) (sending letter which causes annoyance a misdemeanor); State v. McCabe, 135 Mo. 450 (1896) (members of collection agency which sent letter threatening to publicize the indebtedness held liable under statute making it a misdemeanor maliciously to threaten injury to credit and reputation).

${ }^{30}$ See Barton v. State, 88 Tex.Crim.Rep. 368, 227 S.W. 317 (1921), and State v. Hammond, 80 Ind. 80 (1881) (no liability under very broad statute notwithstanding threat to prosecute debtor for obtaining money under false pretenses). 


\section{Civil Liability}

The great bulk of litigation involving debt collection practices is of a civil nature. In the older cases, tort liability was in the main based upon defamation, except in the rare instance where some other long-accepted theory could be construed to cover the practice in question. ${ }^{40}$ Today, however, recognition of the torts of invasion of the right of privacy and intentional infliction of mental anguish has considerably broadened the scope of a collector's civil liability.

Defamation. Whether or not a communication is defamatory per se, ${ }^{41}$ in a great majority of states truth of the publication is recognized as a complete defense. ${ }^{42}$ Hence a collector who can demonstrate the existence of a legally enforceable debt need not ordinarily fear liability from a publication of the amount of the debt due. But a correlative imputation that the debtor is not worthy of credit may be defamatory, for the fact that a debt is outstanding does not necessarily establish unworthiness of credit as true. ${ }^{43}$ On the other hand, the reporting of a delinquent debtor to his employer ${ }^{44}$ or to a mutual

${ }^{40}$ The clear-cut torts such as assault and battery for which the agency might be held liable will not be discussed herein.

4The significance of defamation per se is that no special damages need be shown, whereas otherwise such proof is essential to recovery. With respect to collection cases, per se classification seems to turn on whether or not the person to whom bad credit is imputed is injured with respect to his economic livelihood by the imputation. Yelle v. Cowles Publishing Co., 46 Wash.2d 105, 278 P.2d 671 (1955) (credit important to plaintiff, actionable per se); Hudson v. Slack Furniture Co., 318 Ml.App. 15, 47 N.E.2d 502 (1943) (telegrapher not libeled per se by publication of false wage assignment); Liebel v. Montgomery Ward \& Co., 103 Mont. 370, 62 P.2d 667 (1936) (stenographer's pursuit of occupation not jeopardized by statement "your credit is no good"; thus statement not slanderous per se).

12 Consult Prosser, Torts $\$ 96$ (1955); Rest., Torts $\$ 582$, Comment A (1938).

“Turner v. Brien, 184 Iowa 320, 167 N.W. 584 (1918). Defendant caused to be published by a "trust book and credit company" an item charging plaintiff with refusal to pay a debt and rating him a poor credit risk. The court stated: "It is contended that the publication was true. In its literal interpretation we may assume . . . this . . . right but in the broader scope and purpose of the publication it is not shown to be true. It may be true that the plaintiff owed the defendant a sum of money ... but it is not true or shown to be true that the plaintiff was not worthy of credit. . .." Ibid., at 326-27, 586. Consult also Crellin v. Thomas, 247 P.2d 264 (Utah, 1952) (if persistent misconduct is imputed, proof of a single instance does not suffice); White v. White, 129 Va. 621, 106 S.E. 350 (1921) (proof of partial truth of the imputation is ineffective). Indeed, defense of truth may be dangerous, for the jury may be permitted to find that defendant has reiterated the defamation, and increase the damages accordingly. Hall v. Edwards, 138 Me. 231, 23 A.2d 889 (1942).

4 Dickinson v. Hathaway, 122 La. 644, 48 So. 136 (1909). But in Miller v. Howe, $245 \mathrm{Ky}$. 568, 53 S.W.2d 938 (1932), a "mere collecting agent" was held not to have an interest sufficient to justify a privilege. Several cases have found liability in libel when the communication was peculiarly obnoxious or other factors were present. Vail v. Pennsylvania $R$. Co., 103 N.J.L. 213, 136 Atl. 425 (1927) (letter untrue); Hollenbeck v. Ristine, 114 Iowa 358,86 N.W. 377 (1901) (additional charge of cowardice); Brown v. Vanneman, 85 Wis. 451, 55 N.W. 183 (1893) (charge of general bad credit) ; Over v. Schiffling, 102 Ind. 191, 26 N.E. 91 (1885) (additional charge of "lying"). Consult also cases cited note 66 infra. 
credit organization is usually privileged, ${ }^{45}$ as are all communications which concern subjects with which the writer has a legitimate interest when made to another who has a corresponding interest. ${ }^{46}$ The privilege is conditional only, and is lost if the publication is made in bad faith or as a mere cloak to coerce payment. ${ }^{47}$

A minority of states require justification for the publication even if truthfulness is established. ${ }^{48}$ Under this view the collector is of course more susceptible to liability. Thus, for example, it has been held that a tax collector is responsible for libel for "maliciously" proclaiming publicly, by publishing notices in newspapers, that the debtor had not paid his taxes, which notices were in addition to the notice required by statute. 49

Invasion of the right of privacy. Most courts which have expressly considered the question now recognize the existence of a right of privacy, invasion of which will give rise to a cause of action to recover damages. ${ }^{50}$ This comparatively new and as yet ill-defined tor $t^{51}$ has occasionally resulted in the

${ }^{45}$ Watwood v. Stone's Mercantile Agency, 194 F.2d 160 (App.D.C., 1952) ; HooperHolmes Bureau v. Bunn, 161 F.2d 102 (C.A. 5th, 1947); Diamond v. Krasnow, 136 Pa. Super.Ct. 68, 7 A.2d 65 (1939); Ideal Motor Co. v. Warfield, 211 Ky. 576, 277 S.W. 862 (1925) ; Putnal v. Inman, 76 Fla. 553, 80 So. 316 (1918) ; Woodhouse v. Pawles, 43 Wash. 617,86 Pac. 1063 (1906). The privilege terminates when general publication is made to subscribers who do not have an apparent, present interest in the report. Hanschke v. Merchants' Credit Bureau, 256 Mich. 272, 239 N.W. 318 (1931); King v. Patterson, 49 N.J.L. 417, 9 Atl. 705 (1887). Consult Evans, Legal Immunity for Defamation, 24 Minn. L. Rev. 607,618 (1940).

${ }^{\star 0}$ Prosser, Torts $\$ 95$ (1955).

${ }^{47}$ Tuyes v. Chambers, 144 La. 723, 81 So. 265 (1919); Hartnett v. Goddard, 176 Mass. 326, 57 N.E. 677 (1900); Traynor v. Sieloff, 62 Minn. 420, 64 N.W. 915 (1895).

${ }^{4}$ E.g., N.D. Const.Art. I, $\$ 9$; Hutchins v. Page, 75 N.H. 215, 72 Atl. 689 (1909) (common law); Wertz v. Sprecher, 82 Neb. 834, 118 N.W. 1071 (1908) (special statute).

${ }^{4}$ Hutchins v. Page, 75 N.H. 215, 72 Atl. 689 (1909).

${ }^{50}$ For a compilation of states which are undecided, or have affirmatively recognized or denied the existence of the right, consult Prosser, Torts 636-37 (1955). Very recently a few modifications of that compilation have become necessary. Thus, in Housh v. Peth, 165 Ohio St. 35, 133 N.E.2d 340 (1956), the highest court of Ohio affirmed prior decisions of lower Ohio courts that the right exists in that state. Also, a recent dictum of the Iowa Supreme Court recognizes the right in that state. Bremmer v. Journal-Tribune Publishing Co., - Iowa - , - 76 N.W.2d 762, 765 (1956). On the other hand, the Nebraska Supreme Court in Brunson v. Ranks Army Store, 161 Neb. 519, 73 N.W.2d 803 (1955), disaffirmed the existence of the right in no uncertain terms, and the Wisconsin Supreme Court reaffirmed its position in Judevine v. Benzies-Montanye Fuel Co., 222 Wis. 512, 269 N.W. 295 (1936), of refusing to recognize the right. Yoeckel v. Samonig, 272 Wis. 430, 75 N.W.2d 925 (1956). Thus, at the moment the right is recognized in one form or another in twenty states, Alaska and the District of Columbia, and expressly rejected in only four, while three states limit the right by statute. The minority states are Wisconsin, Nebraska, Rhode Island (Henry v. Cherry \& Webb, 30 R.I. 13, 73 Atl. 97 [1909]), and Texas (Milner v. Red River Valley Publ. Co., 249 S.W.2d 227 [Tex.Civ.App., 1952], and McCullagh v. Houston Chronicle Publ. Co., 211 F.2d 4 [C.A. 5th, 1954]). For the historical background of the right see Hazlitt v. Fawcett Publications, 116 F.Supp. 538, 542-43 (D. Conn., 1953).

"The original statement of the right's confines was very comprehensive indeed: "[T]he protection afforded to thoughts, sentiments, and emotions, expressed through the medium of 
imposition of civil liability for collection activities. Of major significance, in contradistinction to defamation, is that malice is immaterial and truth is no defense to the new tort. ${ }^{52}$

Dean Prosser divides the tort into four distinct categories, one of which involves intrusion upon one's "physical solitude or seclusion." 53 Thus, collectors have been held liable for excessive telephoning of the debtor ${ }^{54}$ or for one call in the middle of the night. ${ }^{55}$ Recovery might also be based on tapping of the debtor's telephone wires, ${ }^{56}$ entering into his quarters, ${ }^{57}$ shadowing him, ${ }^{58}$

writing or of threats, so far as it consists in preventing publication, is merely an instance of the enforcement of the more general right of the individual to be let alone. It is like the right not to be assaulted or beaten, the right not to be imprisoned, the right not to be maliciously prosecuted, the right not to be defamed. . . . The principle which protects personal writings . . not only against theft . . . but against publication in any form, is in reality not the principle of private property, but that of an inviolate personality." Warren and Brandeis, The Right to Privacy, 4 Harv. L. Rev. 193, 205 (1890). Recovery has even been based upon the "happiness" clause of a state constitution. Melvin v. Reid, $112 \mathrm{Cal}$. App. 285, 297 Pac. 91 (1931). Cf. Quina v. Roberts, 16 So.2d 558 (La., 1944) (very broad statute).

82 "Personal ill-will is not an ingredient of the offense, any more than in ordinary case of trespass to person or to property." Warren and Brandeis, op. cit. supra note 51, at 218; Lewis v. Physician's \& Dentist's Credit Bureau, Inc., 27 Wash.2d 267, 177 P.2d 896 (1947). But see Cason v. Baskin, 159 Fla. 31, 30 So.2d 635 (1947), for an intimation that malice may be shown as an alternative to substantial injury in proving damages, once an invasion has been established, and Housh v. Peth, 165 Ohio St. 35, 133 N.E.2d 340 (1956), to the effect that proof of malice to sustain collection of exemplary damages is allowed. Furthermore, truth is no defense. Voneye v. Turner, 240 S.W.2d 588 (Ky., 1951); Davis v. General Finance \& Thrift Corp., so Ga.App. 708, 57 S.E.2d 225 (1950). Similarly, mistake is of no import. Kerby v. Hal Roach Studios, 53 Cal.App.2d 207, 127 P.2d 577 (1942). But cf. Davis v. General Finance \& Thrift Corp., supra.

${ }^{5}$ Consult Prosser, Torts 637 et seq. (1955).

Housh v. Peth, 165 Ohio St. 35, 133 N.E.2d 340 (1956) (one factor). In Wiggins v. Moskins Credit Clothing Store, 137 F.Supp. 764 (E.D. S.C., 1956), it was held that if the creditor's agent annoyed the landlady of the debtor by repeated phone calls at her home over a three-month period, and the agent on occasion used "abusive, vile and opprobrious language," the agent invaded the proprietary interest of the landlady in her home by conduct tantamount to a nuisance, and the creditor would be liable to the landlady for the resultant mental and emotional disturbance. Cf. Brillhardt v. Ben Tipp, Inc., 48 Wash.2d 722, 297 P.2d 232 (1956) (nuisance).

${ }^{85}$ See Bowden v. Spiegel, Inc., 96 Cal.App.2d 793, 796, 216 P.2d 571, 573 (1950) (infliction of mental anguish, but indicating recovery could as well have been based on the theory of privacy).

${ }^{56} \mathrm{McD}$ aniel v. Atlanta Coca Cola Bottling Co., 60 Ga.App. 92, 2 S.E.2d 810 (1939); Rhodes v. Graham, 238 Ky. 225, 37 S.W.2d 46 (1931). Cf. Schmukkler v. Ohio Bell Tel. Co., 116 N.E.2d 819 (C.P. Ohio, 1953) (privilege of telephone company to monitor calls). But cf. Chaplin v. National Broadcasting Co., 15 F.R.D. 134 (S.D. N.Y., 1953) (party to conversation who recorded it and later broadcast it held not liable).

${ }^{57}$ Welsh v. Pritchard, 125 Mont. 517, 241 P.2d 816 (1952) (entry by a landlord); Walker v. Whittle, 83 Ga.App. 445, 64 S.E.2d 87 (1951) (entry by an officer).

${ }^{58}$ Souder v. Pendleton Detectives, - La. —, 88 So.2d 716 (1956). Cf. Schultz v. Frankfort Marine, Accident \& Plate Glass Ins. Co., 151 Wis. 537, 139 N.W. 386 (1913) (shadowing held defamatory). 
investigating the debtor's bank account, ${ }^{59}$ serving an unauthorized order to produce certain documents ${ }^{60}$ and similar activity.

Most collection cases fall into Prosser's category involving the placing before the public of private information which, although true, "violates the common decencies." 61 Here, liability has been found for the creditor's placing in his store window a large sign advertising the debtor's non-payment, ${ }^{62}$ publication in a newspaper of a past-due bill, ${ }^{63}$ sending of unsealed letters addressed to the debtor to the homes of his friends demanding payment, ${ }^{64}$ and telephoning of the debtor concerning the debt at his neighbor's home. ${ }^{65}$ In sum, publication by the creditor or collection agency of the fact that the debtor has not paid his bills may constitute an invasion of the debtor's privacy.

There may be, however, some limitations to recovery under the publication rule. Several cases suggest that the exposure must be to the public generally or at least to a large number of persons ${ }^{66}$ Nevertheless, privacy would seem to be violated by any revelation of the existence of the debt without regard to the number of persons to whom this fact is communicated. The injury to the debtor may be less, but it nonetheless exists.

It may also be argued, by analogy to the law of defamation, that publication of the fact of the debt by one with a legitimate interest in the matter to another with a comparable interest should be privileged. ${ }^{67}$ Under this view,

${ }^{59}$ Cf. Brex v. Smith, 104 N.J. Eq. 386, 146 Atl. 34 (1929).

${ }^{60}$ Cf. Frey v. Dixon, 141 N.J. Eq. 481, 58 A.2d 86 (1948).

${ }^{01}$ This is Dean Prosser's fourth category. The second category consists in appropriation of an element of plaintiff's personality, as his picture, and subjecting it to commercial uses. A third group of cases involves a putting of plaintiff before the public in a false, although not defamatory, manner, for instance by signing his name to a public telegram which attributes to him views he does not hold. These latter categories will not ordinarily involve the collector.

In collection cases the unwarranted publicity aspect is generally more strongly emphasized than the intrusion upon solitude and perhaps a more extraordinary case of abuse will be required to admit of recovery without the additional factor of publicity. To the effect that conduct, reasonable between the parties, may be unreasonable when published to third parties, see McKinzie v. Huckaby, 112 F.Supp. 642 (W.D. Okla., 1953).

${ }^{62}$ Brents v. Morgan, 221 Ky. 765, 299 S.W. 967 (1927) ; Thompson v. Adelberg \& Berman, $181 \mathrm{Ky} .487,205$ S.W. 558 (1918).

Trammel v. Citizens News Co., 285 Ky. 529, 148 S.W.2d 708 (1941).

at Cf. Cyran v. Finlay Straus, Inc., 302 N.Y. 486, 99 N.E. 2d 298 (1951) (debt had already been paid, recovery had for libel).

${ }^{{ }^{a 5}}$ See Bowden v. Spiegel, Inc., 96 Cal.App.2d 793, 216 P.2d 571 (1950) (intentional infliction of mental anguish, the court stating its view that the right of privacy was also invaded).

${ }^{\infty 8}$ Consult Lucas v. Moskins Stores, 262 S.W.2d 679 (Ky., 1953); Voneye v. Turner, 240 S.W.2d 588 (Ky., 1951) ; Patton v. Jacobs, 118 Ind.App. 358, 78 N.E.2d 789 (1948); Lewis v. Physician's \& Dentist's Credit Bureau, 27 Wash.2d 267, 177 P.2d 896 (1947).

o: Consult Warren and Brandeis, op. cit. supra note 51, at 217. Rest., Torts \$867, Comment C (1939), suggests an analogy to the "fair comment" defamation cases. Consult Collection Methods, 26 Rocky Mtn. L. Rev. 347 (1953). 
a letter to a credit association is conditionally privileged. ${ }^{68}$ Communication to the debtor's employer has been held to be similarly protected. ${ }^{69}$ However, it may be questioned whether or not the employer has any interest different from that of the public generally. At best, the employer may show concern over his employee's welfare, discharge financially unstable employees, or perhaps give them a raise. Similarly, any stranger may show interest in the welfare of his fellow humans, disassociate himself from the irresponsible, and give to the needy. The usual rationale-expenses of a possible garnishment suit-hardly seems weighty. Moreover, from the creditor's point of view, a publication to the debtor's employer would seem to be based on a feeling that such will tend to coerce payment, presumably by threat of discharge, ${ }^{70}$ and might therefore be held "unwarranted" or "oppressive." Thus, extension of a privilege allowing communication of the fact of a debt to the debtor's employer would appear unjustified.

Intentional infliction of mental anguish. Creditors and their agencies have often been held liable in damages for the intentional infliction of mental anguish. The earliest such case involved an undertaker's delay in cremation to coerce payment of a bill, and has become a leading case. ${ }^{71}$ Other cases on their facts seem analogous, but were decided on long-accepted theories. ${ }^{72}$ At present, the independent tort is generally recognized, although limited to cases of "outrageous" conduct. ${ }^{73}$ There is also a definite trend away from the

* Cases cited note 45 supra.

${ }^{*}$ Cases cited note 66 supra, none of which, however, expressly mentioned a privilege in these terms. Also consult cases in note 44 supra.

${ }^{70}$ Consult La Salle Extension University v. Fogarty, 126 Neb. 457, 253 N.W. 424 (1934): "Our company wasn't having men working for us who had their salaries garnisheed, and if in case he had anything like that, we would have to do one thing or the other, either pay the bills or have to dismiss him." Ibid. at 460,425 .

${ }^{71}$ Gadbury v. Bleitz, 133 Wash. 134, 233 Pac. 299 (1925).

${ }^{72}$ Those courts which seek to avoid overt acceptance of the new tort reach the same result by finding some other technical tort, after which damages are recovered for mental suffering as well as for the technical breach. Housh v. Peth, 165 Ohio St. 35,133 N.E.2d 340 (1956) (invasion of right of privacy); Manning v. Kennedy, 320 Il.App. 11, 49 N.E.2d 658 (1943) (conspiracy); Deevy v. Tassi, 21 Cal.2d 109, 130 P.2d 389 (1942) (battery); Continental Casualty Co. v. Garrett, 173 Miss. 676, 161 So. 753 (1935) (trespass to land); Atlanta Hub Co. v. Jones, 47 Ga.App. 778, 171 S.E. 470 (1933) (technical assault) ; Salisbury v. Poulson, 51 Utah 552, 172 Pac. 315 (1918) (false imprisonment); Whitsel v. Watts, 98 Kan. 508, 159 Pac. 401 (1916) (technical assault); Shellabarger v. Morris, 119 Mo.App. 566, 91 S.W. 1005 (1905) (nuisance).

${ }^{33}$ Consult Prosser, Insult and Outrage, 44 Cal. L. Rev. 40 (1956). Ohio is the only state which, having recently considered the matter, still absolutely refuses to recognize this tort. Bartow v. Smith, 149 Ohio St. 301, 78 N.E.2d 735 (1948). A similar view was taken in Harned v. E-Z Finance Co., 151 Tex. 641, 254 S.W.2d 81 (1953), but that case was very strongly criticized in Green, "Mental Suffering" Inflicted by Loan Sharks No Wrong, 31 Tex. L. Rev. 471 (1953), and was modified in Duty v. General Finance Company, 154 Tex. 16, 273 S.W.2d 64 (1954). The Restatement of Torts considerably liberalized its position in the 1948 supplement, and now takes the view that: "One who, without a privilege to do so, intentionally causes severe emotional distress to another is liable (a) for such emo- 
requirement of some physical injury before damages for mental suffering are permitted. ${ }^{74}$

Collection practices of a wide variety have been held, either singly or in combination, sufficiently "outrageous" to constitute the intentional infliction of mental anguish. Broadly speaking, such practices fall into two categories: those which directly disrupt the debtor's peace of mind and those which do so indirectly, through the economic and social pressure of others. The first type of harassment has taken the form of an excessive number of demanding communications, ${ }^{75}$ and threats to blacklist, ${ }^{76}$ garnishee wages, ${ }^{77}$ exercise self help ${ }^{78}$ institute criminal proceedings ${ }^{79}$ or reveal the non-payment to employers $^{80}$ or neighbors. ${ }^{81}$ The use of abusive and vulgar language and accusations of bad character in the making of such communications or threats is also relevant. ${ }^{82}$ The second group of proscribed activities comprehends actual

tional distress and (b) for bodily harm resulting from it." Rest., Torts $\$ 46$ (Supp., 1948).

The limitation of the requirement of outrageous conduct is dictated by aversion to trivial litigation over minor annoyances. Magruder, Mental and Emotional Disturbance in the Law of Torts, 49 Harv. L. Rev. 1033 (1936). Also, when the annoyance or insult is petty, there is a conspicuous lack of assurance that there has been any mental suffering. Thus, profanity and abuse alone do not ordinarily give rise to a caúse of action. Ex parte Hammett, 259 Ala. 240, 66 So.2d 600 (1953). See further cases cited by Prosser, supra, at 45-66.

${ }^{74}$ State Rubbish Collectors Ass'n v. Siliznoff, 38 Cal.2d 330, 240 P.2d 283 (1952); Quina v. Roberts, 16 So.2d 558 (La., 1944). Perhaps an increasing recognition that mental and emotional disturbances are actually physical injuries themselves has been influential in this change. Consult Smith, Relation of Emotion to Injury and Disease: Legal Liability for Psychic Stimuli, 30 Va. L. Rev. 193 (1944); Earangey, The Legal Consequences of Shock, 2 Medico-Leg. \& Crim. Rev. 14 (1934). See also Davidson v. Lee, 139 S.W. 904 (Tex.Civ. App., 1911).

Concerning mere negligent infliction of mental anguish as giving rise to liability consult Prosser, op. cit. supra note 73 , at 54 et seq., and Gregory, Toelle and Sykes, The Interest in Freedom from Mental Disturbance, 27 Conn. B.J. 65 (1953), discussing Urban v. Hartford Gas Co., 139 Conn. 301, 93 A.2d 292 (1952) (allowing such recovery although perhaps recklessness was involved). Examples of the nearly unanimous view that wilful conduct is required are Espisona v. Beverly Hospital, 114 Cal.App.2d 232, 249 P.2d 843 (1953), and Zabron v. Cunard Steamship Co., 151 Iowa 345, 131 N.W. 18 (1911).

${ }^{75}$ La Salle Extension University v. Fogarty, 126 Neb. 457, 253 N.W. 424 (1934). Cf. Clark v. Associated Retail Credit Men, 105 F.2d 62 (App. D.C., 1939) (threatening letters to plaintiff known to be ill).

${ }^{\pi}$ Duty v. General Finance Co., 154 Tex. 16, 273 S.W.2d 64 (1954).

IIbid.

${ }^{78}$ Digsby v. Carroll Baking Co., 76 Ga.App. 656, 47 S.E.2d 203 (1948). Cf. Peoples Finance \& Thrift Co. v. Harwell, 183 Okla. 413, 82 P.2d 994 (1938) (threat to repossess household furniture, including pregnant woman's bed).

${ }^{72}$ Kirby v. Jules Chain Stores Corp., 210 N.C. 808, 188 S.E. 625 (1936). Cf. Quina v. Roberts, 16 So.2d 558 (La., 1944) (simulation of legal documents).

${ }^{80}$ Barnett v. Collection Service Co., 214 Iowa 1303, 242 N.W. 25 (1932).

${ }^{81}$ Cf. Kirby v. Jules Chain Stores Corp., 210 N.C. 808, 188 S.E. 625 (1936).

${ }^{82}$ Digsby v. Carroll Baking Co., 76 Ga.App. 656, 47 S.E.2d 203 (1948) ; Kirby v. Jules Chain Stores Corp., 210 N.C. 808, 188 S.E. 625 (1936) ; Barnett v. Collection Service Co., 
revelation of the debtor's financial circumstances to his family, ${ }^{83}$ neighbors, ${ }^{84}$ employer, ${ }^{85}$ credit associations $^{86}$ and the public generally. ${ }^{87}$ Similarly included are the more indirect modes of publicity, such as sending threatening postcards, ${ }^{88}$ telegrams, ${ }^{89}$ letters on the envelopes of which are cleverly worded and depicted indications of the letter's purpose, ${ }^{90}$ or leaving handbills or notices in and around the debtor's residence. ${ }^{91}$

The collection method utilized in a particular instance is not the sole determinant in the imposition of tort liability. The collector's activities may be desultory or oft-repeated. The debtor may be a widow, ${ }^{92}$ pregnant woman ${ }^{93}$ or wife at home alone. ${ }^{94}$ The amount due may be extremely small ${ }^{95}$ or perhaps not owing at all. ${ }^{96}$ Finally, the collector may be a mere creditor, or an agency making a business out of the collection of debts. ${ }^{97}$

214 Iowa 1303, 242 N.W. 25 (1932) (coarse, vindictive letters to widow). In the Digsby case it was also alleged that this agent used such language as "lasciviously" to suggest that "if he could not get the money any other way he was going to 'take it out in trade,' meaning he was going to have sexual intercourse with petitioner," simply "adding insult to injury." Supra, at 660, 206.

Duty v. General Finance Co., 154 Tex. 16, 273 S.W.2d 64 (1954).

* Bowden v. Spiegel, 96 Cal.App.2d 793, 216 P.2d 571 (1950); La Salle Extension University v. Fogarty, 126 Neb. 457,253 N.W. 424 (1934).

${ }^{85}$ Duty v. General Finance Co., 154 Tex. 16, 273 S.W.2d 64 (1954); Quina v. Roberts, 16 So.2d 558 (La., 1944); La Salle Extension University v. Fogarty, 126 Neb. 457, 253 N.W. 424 (1934).

${ }^{80}$ Duty v. General Finance Co., 154 Tex. 16, 273 S.W.2d 64 (1954).

${ }^{87}$ American Security Co. v. Cook, 49 Ga.App. 723, 176 S.E. 798 (1934) (kicking at front door, kicking in screen of back door, cursing plaintiff in presence of others).

Duty v. General Finance Co., 154 Tex. 16, 273 S.W.2d 64 (1954).

${ }^{\infty}$ Ibid.

${ }^{\circ 0}$ La Salle Extension University v. Fogarty, 126 Neb. 457, 253 N.W. 424 (1934) (lurid envelopes, one of which bore a facsimile of lightning about to strike).

${ }^{91}$ Duty v. General Finance Co., 154 Tex. 16, 273 S.W.2d 64 (1954).

${ }^{22}$ Barnett v. Collection Service Co., 214 Iowa 1303, 242 N.W. 25 (1932).

${ }^{*}$ Peoples Finance \& Thrift Co. v. Harwell, 183 Okla. 413, 82 P.2d 994 (1938).

* Digsby v. Carroll Baking Co., 76 Ga.App. 656, 47 S.E.2d 203 (1948).

${ }^{\infty}$ E.g., Quina v. Roberts, 16 So.2d 558 (La., 1944) (\$1.45).

When the debt is not legally collectible, the outrageousness seems more gross, and liability more likely to ensue. Barnett v. Collection Service Co., 214 Iowa 1303, 242 N.W. 25 (1932) (defendant "should have known" the debt could not legally be collected); La Salle Extension University v. Fogarty, 126 Neb. 457, 253 N.W. 424 (1934) (plaintiff sued to recover the amount allegedly due; held not collectible); Maze v. Employee's Loan Soc., 217 Ala. 44, 114 So. 574 (1927) (contested amount).

${ }^{n}$ When defendant is a creditor corporation it seems to fare no better than a collection agency. But a private creditor may be viewed with more compassion by the courts. In McKinzie v. Huckaby, 112 F.Supp. 642 (W.D. Okla., 1953), the creditor brought a policeman, who stayed in the creditor's car, and plaintiff was so disturbed that be became ill. The court refused to find liability, because defendant had no knowledge of any "peculiar susceptibility of mental strain." 
It may be suggested that collectors have in many instances been held liable for something less than the "outrageous" conduct generally stated to be required. Thus, mere insults, threats and accusations do not ordinarily give rise to civil recovery..$^{98}$ Furthermore, there is surely a legal right or at least a privilege to make some extra-judicial attempt at collecting outstanding claims, even if done in bad grace.

Three explanations may be suggested for this phenomenon. First, something less than "outrageousness" has been required by many courts where there have been physical injuries, for the outrage requirement is in part based on the fear that the annoyance may be trivial, a fear unjustified in the face of physical injury. ${ }^{99}$ There is, however, little empirical support for this explanation, since most collection cases finding liability involve only mental suffering. Alternatively, it will be noted that the major purpose of the collector in pressuring the debtor may be a desire to cause anxiety and thereby hasten payment of the debt. Thus, if the collector has created mental suffering, he has only succeeded in doing exactly what he intended to accomplish. ${ }^{100}$ Finally, it has been stated that the outrageous character of an act arises "not so much from what is done as from the abuse by the defendant of some relation with the plaintiff or some position which gives him actual or apparent authority over the plaintiff or power to damage his interest."101 By and large, this view would appear to be an apt explanation for the many recoveries against collectors based upon the intentional infliction of mental anguish. ${ }^{102}$

The nere tort? It is apparent that the theories upon which the collector may be held liable in tort overlap to a considerable degree. If the collection activities are directed solely at the debtor, both invasion of the right of privacy

\footnotetext{
${ }^{8}$ Consult Prosser, Insult and Outrage, 44 Calif. L. Rev. 40 passim (1956), and discussion in note 73 supra.

${ }^{9}$ Consult discussion in note 73 supra.

${ }^{100}$ Consult La Salle Extension University v. Fogarty, 126 Neb. 457, 253 N.W. 424 (1934); Barnett v. Collection Service Co., 214 Iowa 1303, 242 N.W. 25 (1932).
}

${ }^{101}$ Prosser, op. cit. supra not 98 , at 45 . "The principle is much the same as that underlying our criminal statutes on extortion and blackmail, or the common law liability for abuse of process." Ibid.

${ }^{102}$ Similar liability has been imposed upon evicting landlords who behave outrageously, as by tearing up the premises, smoking out tenants, or screaming abuse. Richardson v. Pridmore, 97 Cal.App.2d 124, 217 P.2d 113 (1950); Emden v. Vitz, 88 Cal.App.2d 313, 198 P.2d 696(1948). Likewise, bullying activity of insurance adjusters leads to liability. E.g., Interstate Life and Accident Co. v. Brewer, 56 Ga.App. 599, 193 S.E. 458 (1937). To the same effect are: National Life \& Accident Ins. Co. v. Anderson, 187 Okla. 180, 102 P.2d 141 (1940) ; Pacific Mutual Ins. Co. v. Tetirick, Gdn., 185 Okla. 37, 89 P.2d 774 (1938) ; Continental Casualty Co. v. Garrett, 173 Miss. 676, 161 So. 753 (1935). Cf. Johnson v. Sampson, 167 Minn. 203, 208 N.W. 814 (1926); Janvier v. Sweeney [1919] 2 K.B. 316; Curnett v. Wolff, 244 Iowa 683,57 N.W.2d 915 (1953) (threat to have plaintiff discharged if he did not dismiss a suit). 
and intentional infliction of mental anguish may result. Or, if the collector resorts to the aid of others, the two sorts last mentioned and defamation may be found. Furthermore, any attempt to distinguish the theories applicable to either situation would seem difficult. In the former instance, there is an intrusion upon the debtor in order to disturb his peace of mind. In the latter, there is a publication revealing the debtor's financial affairs intended to cause anxiety which also carries with it an imputation of poor credit. It is thus not surprising that defamation, the right of privacy and freedom from mental suffering are used almost interchangeably when the liability of collectors is in issue. If, for example, one of these theories is not recognized in a particular jurisdiction, a case which most appropriately falls under that theory is likely to be decided on an alternative basis. Such has happened, for example, in Wisconsin, ${ }^{103}$ Ohio, ${ }^{104}$ Texas $^{105}$ and Nebraska. ${ }^{106}$ Similarly, cases falling analytically closer to one theory are often decided under another.

In sum, the tort liability of collectors presently rests on an amorphous and doctrinally unsatisfying body of law. It may be suggested that eventually one existing theory may absorb all, ${ }^{107}$ or that a new and independent theory dealing only with collectors will be developed, much as has been done in regard to common carriers. Under either alternative, analysis would be promoted, certainty increased, and progress made toward isolating the real issues. However, neither alternative seems probable. Instead, it may be expected that liability will continue to rest on several theories, in large measure dependent upon the available precedents. Nor is this situation particularly undesirable. Given a sympathetic court, the flexibility today possible would seem well suited to a just accommodation of the sometime conflicting interests of collectors and debtors in regard to the collection of debts.

${ }^{108}$ Compare Yoekel v. Samonig, 272 Wis. 430, 75 N.W.2d 925 (1956) (no right of privacy), with Schultz v. Frankfort Marine Accident \& Plate Glass Ins. Co., 151 Wis. 537, 139 N.W. 386 (1913) (defamation).

${ }^{104}$ Compare Housh v. Peth, 165 Ohio St. 35, 133 N.E.2d 340 (1956) (right of privacy), with Bartow v. Smith, 149 Ohio St. 301, 78 N.E.2d 735 (1948) (no intentional infliction of mental anguish).

${ }^{100}$ Compare Duty v. General Finance Co., 154 Tex. 16, 273 S.W.2d 64 (1954) (intentional infliction of mental anguish), with Milner v. Red River Valley Publ. Co., 249 S.W.2d 227 (Tex.Civ.App., 1952) (no right of privacy).

${ }^{100}$ Compare La Salle Extension University v. Fogarty, 126 Neb. 457, 253 N.W. 424 (1934) (intentional infliction of mental anguish), with Brunson v. Ranks Army Store, $161 \mathrm{Neb}$. 519, 73 N.W.2d 803 (1955) (no right of privacy).

${ }^{100}$ Thus, Dean Prosser suggests that when the tort of intentional infliction of mental anguish becomes fully developed "the great majority of privacy cases may . . . be absorbed into it." Prosser, Torts 639 (1955). 